\title{
New Periodicals and Serials
}

$T_{\text {He following annotated list of recently launched periodicals and serials has been }}$ contributed by Carolyn F. Ulrich, chief, periodicals division, New York Public Library, and in this issue when so initialed, by Wyllis E. Wright, chief cataloger, New York Public Library, and Dorothy H. Litchfield, supervisor, periodicals and microfilms, Columbia University Library.

America Looks Ahead; a Pamphlet Series. Published by the World Peace Foundation, $40 \mathrm{Mt}$. Vernon St., Boston. No. I, Jan. 194I. Frequency and price not given.

"Expert but condensed comment on ... inter. national issues."

Amerind Foundation, Inc. [Publications.] Dragoon, Ariz. No. I, 1940. Frequency and price not given.

The purpose of the Amerind Foundation is the fostering of scientific, educational, and archaeological studies. W.E.W.

Annals of Mathematics Studies. Princeton University Press, Princeton, N.J. No. I, 1940. Ir regular. Price not given.

Community Councils in action. Published by the American Association for Adult Education, 6o E. 42nd St., New York. Vol. I, No. I, Dec. 1940. Irregular. Price not given.

"In the defense of a Democratic Culture." Con. tains book reviews.

Decision; a Review of Free Culture. Decision, Inc., I4I E. 29th St., New York. Vol. I, No. I, Jan. I94I. Monthly. \$4 a year.

Edited by Klaus Mann and an editorial board of prominent American and European writers. Con. tains book reviews.

Engineers' Digest; Review of Engineering Progress Abroad. Published by Engineers' Digest, Ltd., 59 Weymouth St., London, W.I. Vol. I, No. I, June 1940. Monthly. $\mathfrak{t}_{2.20}$ a year.

Well illustrated, including excellent diagrams and graphs.

FM ; the Complete and Authoritative Source of Information on Frequency Modulation. FM Company, Box 235, South
Norwalk, Conn. Vol. I, No. I, Nov. 1940. Monthly. \$3 a year.

Well illustrated and excellent diagrams.

Fakkel; in Handen van Allen, die Deel Habben aan het Nederlandsche Cultuur-en Geestesleven. Koninklijke Drukkerij De Unie, Batavia, Java. Vol. I, No. I, Nov. 1940. Monthly. $\mathfrak{E}_{15}$ a year.

General cultural publication.

Folklore; Boletin del Departamento de Folklore del Instituto de Cooperación Universitaria. Instituto de Cooperación Universitaria Reconquista 572, Buenos Aires. No. I, Sept. 1940. Frequency and price not given.

A medium for the promulgation of Argentinian folklore information.

Indian Journal of Social Work. Edited by the Faculty of the Sir Dorabji Tata Graduate School of Social Work, Bombay, India. Vol. I, No. I, June I940. Rs. Io/ a year.

Covers juvenile delinquency in India. Case studies; research reports; news from the field; book reviews; bibliography.

Inter-Allied Review; a Monthly Résumé of Documents Relating to the Allied Struggle for Freedom. Published by the Inter-Allied Information Centre, 6ro Fifth Ave., New York. No. I, Jan. I94I. Io\& a copy.

Lawyers Guild Review. Published by the National Lawyers Guild, I653 Pennsylvania Ave., N.W., Washington, D.C. Vol. I, No. I, Oct. 1940. Bimonthly. \$1.50 a year.

Successor to National Lazeyers Guild Qwarterly. Contains book reviews.

Leland Stanford Junior University. Hoover Library on War, Revolution, and Peace. 
Miscellaneous Publication. Stanford University Press, California. No. I [194I].

Frequency and price not given.

W.E.W.

Massachusetts Archaeological Society. Contributions. I654 Massachusetts Ave., Cambridge, Mass. No. I, I94I. Frequency and price not given.

Medical Care; Economic and Social Aspects of Health Service. Williams and Wilkins Company, Baltimore. Vol. I, No. I, Winter I94I. Quarterly. \$I a copy.

Modern Industry; for All Management Men Concerned with Making and Marketing Better Products at Lower Cost. Published by the Magazine of Industry, 347 Madison Ave., New York.

Illustrated.

North Carolina University. Library. Hanes Foundation Publications. Chapel Hill, N.C. No. I, 1940. Frequency not given. Price varies.

"Established to aid the study of the origin and development of the book."

Physical Educator; Official Publication of Phi Epsilon Kappa Fraternity. (Affiliated with the American Association for Health, Physical Education, and Recreation.) I 537 W. 29th St., Indianapolis. Vol. I, No. I, Oct. I940. Five times a year. \$I.50 a year.

Public Administration Review; Journal of the American Society for Public Administration. I313 E. 6oth St., Chicago. Vol. I, No. I, Autumn 1940. Quarterly. \$5 a year.

"To advance the science, processes, and art of public administration." Reviews of books and documents.

Review Index: a Quarterly Guide to Professional Reviews for College and Refer- ence Libraries. Follett Book Company, I255 S. Wabash Ave., Chicago. \$3.50 a year.

A book selection guide which will index more than 6000 professional reviews every year, including reviews of foreign books.

School and College Placement; Journal of the Pennsylvania Association of School and College Placement. 3400 Walnut St., Philadelphia. Vol. I, No. I, Sept. I940. Quarterly. \$2 a year.

Study and research into placement procedure. Contains book reviews.

Studies in American Foreign Relations. Published by the Council on Foreign Relations. 45 E. 65th St., New York. No. I [194I]. Irregular. Price varies.

W.E.W.

Studies in the Control of Radio. Published by the Radiobroadcasting Research Project at the Littauer Center of Harvard University. [Cambridge, Mass.] No. I, Nov. 1940. Irregular. 50 $\phi$ a copy.

W.E.W.

Studium; Organo de los Estudiantes Universitarios de Guatemala. Pasaje Aycinena 2I, Guatemala City. Vol. I, No. I, Jan. 194I. Quarterly. \$2 a year.

Reports of research and theses by faculty and students in the schools of medicine; odontology; natural and pharmacal sciences; economics; engi-
neering.
D.H.L.

Ukazatel' Literatury po Mezhdunarodnomu Polozheniyu. Published by the Vsesoyuznaya Knizhnaya Palata, ul. Chaikovskogo 20, Moscow, U.S.S.R. I940. Semiannual. Price varies.

Guide to the literature on international affairs arranged by subject, with author, subject, and source index.

Young America's Aviation Annual. R. M. McBride and Company, New York. $1940 / 41$. \$2.

A survey of the advances in aviation in the U.S. Profusely illustrated. 


\section{Recent Literature on Higher Education}

He Following annotated list has been compiled by Clara Esther Derring and Carrie
E. Meares of Teachers College Library, Columbia University.

Brown, Francis J. "Education and Our National Defense." Harvard Educational Review II:56-67, Jan. I94I.

"The author, a member of the faculty of New York University, assigned by the American Council on Education to the difficult task of coordinating educational values and national defense needs, here writes of the situation today as seen from the vantage point of the nation's capital,"

Goode, Delmer. "The Catalog and the Curriculum." Journal of the American Association of Collegiate Registrars 16: I92-20I, Jan. I94I.

A sketch of the curricular situation in American higher education today and a consideration of the curriculum in relation to the catalog are given.

"There is general agreement in regard to what is appropriately included in a college catalog, but is appropriately included in a college catalog, but specific questions nevertheless arise for which score
cards and other aids do not afford the answers. cards and other aids do not afford the answers. must be decided in terms of the particular catalog that is under preparation, the curriculum of the institution, it is believed, affords the basis for decision. Any element has a claim for consideration for place in the catalog to the extent that it is related to the educational program. Items such as calendar, campus map, the governing board the administrative and instructional staffs are obviously related to the course offerings."

Gray, William S. "Summary of Reading Investigations." Journal of Educational Research 34:401-43, Feb. I94I.

A comprehensive summary of researches pub. lished in this area during the past year.

"Liberal Education and Democracy." $A s$ sociation of American Colleges Bulletin 27 :6-104, Mar. I94I.

The general topic "Liberal Education and De. mocracy" was the concern of the twenty-seventh annual meeting of the Association of American Col leges in Pasadena, January, I94I. The papers and general discussion revolved around the report which is being prepared for the American Council of Learned Societies by Prof. Theodore M. Greene of Princeton University.

Smith, Henry Lester. "Trends in Higher Education." Journal of Higher Education I 2:122-28, Mar. I94I.

Problems of population, public and private sup port, accrediting agencies, and the significance of individual differences are discussed.

Wilkins, Ernest H. "The Professor Ad- ministrant." Bulletin of the American Association of University Professors 27: I8-28, Feb. I941.

"If teaching, learning, and research are the central processes of a college or university, then it is obviously much to be desired that the main administrative officers should understand the essential character, the purposes, and the problems of teaching learning, and research. This means, in practical terms, that presidents and deans should usually be men or women who have had the experience of professorship-though it is undoubtedly for the good of the professor that there should be some few who come in by other routes... Deans and presidents come in by other routes. . . Deans and pres.

There follows an analysis of what happens when a professor becomes a professor administrant. What happens to him, and what happens to his colleagues with respect to their attitudes and feelings in regard to him?

Byrne, Charles D. Coordinated Control of Higher Education in Oregon. Stanford University Press [c1940]. I 50p. \$2.75. A study of the operation and functioning of Oregon's State System of Higher Education.

Ch'en, Hsi-en. Developing Patterns of the College Curriculum in the United States. Los Angeles, Calif., University of Southern California Press [c1940]. I 54p. Apply. (Southern California Education Monographs. No. IO.)

The author describes "six different patterns of the curriculum which seem to be emerging from current attempts to reorganize the liberal arts cur. riculum." Bibliography, p. 143-54.

McNeely, John H. Fiscal Control over State Higher Education. U.S. Government Printing Office, I940. 49p. Io $\varnothing$ (U.S. Office of Education. Bulletin 1940, No. 8.)

This study is the seventh of a series on the various aspects of the relation of the state to higher education. "It concerns the fiscal control vested in the state executive officers or agencies over state universities and colleges. Practically all of the state universities and colleges. Practically all of the
states have recently taken steps toward the instates have recently taken steps toward the in
creased centralization of fiscal control over the various units comprising the state governmenta organization in such officers or agencies. Inasmuch as the governing boards of these institutions were originally endowed with considerable autonomy over their financial affairs the transfer of this control to central state officers or agencies raises problems of central state officers or agencies raises problem.

(Continued on page 288) 


\section{PERIODICAL EXCHANGE UNION}

The Board of Directors of the Association of College and Reference Libraries have voted unanimously to endorse a plan for a duplicate periodical exchange union which is outlined below. This plan was published in the February 15, 1940, issue of the $L i$ brary Journal. Since that time seventeen libraries have agreed to try out these suggestions, and five other libraries have indicated substantial interest in the plan, if it could be put into operation. It is hoped that the plan may be initiated by July I, I94I, and that before that time many other libraries will indicate that they are willing to give it a trial.

The essential points of the plan for a periodical exchange union as approved by the Association of College and Reference Libraries are as follows:

I. Member libraries will agree to the free exchange policy, thus eliminating much record keeping and circumventing money difficulties.

2. Each library will list its duplicates, giving volume, number, and date.

3. These lists will be circulated among the participating libraries in the order of the size of their annual budget for periodicals. Libraries putting most money into periodicals will have priority over the others. Presumably most of the material large libraries will need will be more rare and difficult to obtain than that desired by smaller libraries. The advantage to smaller libraries of access to duplicate material of large libraries offsets this priority of choice.

4. As these lists pass from one library to another, items required by any library will be crossed off the list by that library, and requested from the library owning them. The receiving library will pay carriage charges. Libraries will be asked to keep a record of the number of pieces of bound and unbound material sent to and received from members of the exchange union.

5. Libraries desiring to become members of the exchange union are urged to send their lists of periodical budget figures to Fisk University Library, Nashville, Tenn., Neil C. Van Deusen, librarian, as long as possible before July I. A routing list will then be prepared by the Fisk University Library staff, and will be submitted to the American Library Association statistical staff, as a neutral agency, for checking against their records of periodical budgets. Fisk University Library will undertake to mimeograph the routing sheets and to mail them to all participating libraries. Each library will then forward its list of periodical duplicates to the first library on the list, and the plan will be in operation.

Neil C. Van Deusen, Librarian Fisk University

\section{Recent Literature on Higher Education}

\section{(Continued from page 279)}

"This bulletin contains an analysis of the policies and practices adopted by the individual state with respect to this subject." Foreword.

Monroe, Walter S., ed. Encyclopedia of Educational Research. Prepared under the auspices of the American Educational Research Association. Macmillan [ci94I]. I344p. \$1o.

A critical synthesis and interpretation of research in the field of education. The articles are signed. Selected bibliographies.
Russell, John D., comp. and ed. Student Personnel Services in Colleges and Universities. University of Chicago Press [cI94I]. 30op. \$2.50. (Institute for Administrative Officers of Higher Institutions. Proceedings. Vol. 12, 1940.)

The following phases of the subject are included: (I) The obligation of the institution to its students; (2) Administrative organization for student personnel services; (3) Institutional provisions for understanding students; (4) Interpretation and use of data in counselling students; and (6) Evaluation of student personnel services. 